Ann. Génét. Sél. anim., 1976, 8 (1), 89-10r.

\title{
REVIEW \\ SOME CONSIDERATIONS \\ ON SELECTION CRITERIA AND OPTIMIZATION FOR TERMINAL SIRE BREEDS ( $\left.{ }^{1}\right)$
}

\author{
J. L. FOULLEY \\ Station de Génétique quantitative et appliquée, \\ Centre national de Recherches zootechniques, I. N. R. A., \\ 78350 Jouy en Josas
}

\section{SUMMARY}

The efficiency of selection of beef breeds for terminal crossing has been analysed in terms of selection criteria for growth and methods for selection of sires, notably with reference to the situation and research in France.

With respect to selection of specialized beef lines, the advantage of control of the individual feed intake and of carcass performances as compared to control of growth only is shortly discussed. For this purpose, not only the favourable indirect response but also the resulting increment of feed intake and changes in body composition according to the reference system used (weight, duration, age) should be taken into account.

Because of the increase in birth weight due to the intensification of selection for muscle growth within the beef breeds and the strong genetic correlation between this weight and the paternal component of calving difficulties, it seems advisable to use restricted indices for selection on birth weight, at least for terminal sire lines used in heifers.

In the French situation of terminal crossing practised on suckling cows of dual purpose or hardy breeds with the aim of producing veal calves, a special attention has been paid to the genetic and economic advantage of two stage selection for choosing bull sires : selection on a station performance test (1 2-month-weight), selection on a field progeny test (3-month-weight). Although progeny testing is absolutely required for this type of selection, it has not necessarily to be applied to AI bulls before their commercial use ; it might be sufficient to choose the bulls after performance testing provided the latter is realized on sons of elite bulls.

\section{INTRODUCTION}

Utilization and selection of specialized sire lines for crossing of beef breeds have been clearly demonstrated by theoretical (SMITH, I964; MoAV, I966; MOAV and HILL, I966), experimental (Cundiff, I974) and economical (Cunningham, I974; CARTwright and Fitzhugh, i 974) considerations as well in suckling as in dairy herds.

(1) Report presented at the first European Economic Community (E.E.C.) Genetic Seminar on " Optimization of Cattle Breeding Schemes ", Dublin, Ireland, November 26-28th, 1975. 
France is much concerned by terminal crossing on account of the great number of AI performed for this purpose (about 2 millions), the availability of beef breeds and the efforts made to set $\mathrm{np}$ an integrated selection scheme.

As pointed out by HiLl (I97I), two separate aspects are to be considered $: i$ ) the choice of breeds, $i$ ) the choice of selection programmes maximizing the efficiency of selection. The first important point of comparaison of the relative merit of different terminal sire beef breeds or lines will not be discussed here. Furthermore, the optimization methods of breeding schemes will be divided into two parts : genetic and economic.

For genetic considerations, it is not the purpose of the author to present an exhaustive review of objectives and criteria for selection of a terminal beef breed after the very comprehensive previous papers, especially those of Cartwright (1970), Preston and Willis (1970) and MeNissier et al. (1975). Therefore only two topics related to selection on growth will be considered as growth for a terminal sire line appears to be the most important factor to be controlled genetically.

After trying to elucidate selection criteria for fattening efficiency and improvement of calving ability, some results will be supplied about theoretical optimization of selection procedures for a terminal sire line.

\section{GROWTH, CONSUMPTION, FEED EFFICIENCY}

\section{AND BODY COMPOSITION}

Many studies have been reported on these topics (КоcH et al., 1963; GREGORY, 1965 ; TAYLOR, I97I ; FITZHUGH and TAYLOR, 197I). Only some general results will be supplied here and only not entirely elucidated questions for which there is no general agreement will be treated.

- Rather high genetic variability exists for growth rate and appetite and these two traits are very highly correlated genetically : Preston and Willis (1970), PetTy and CartWRIGHT (I966) indicate heritability mean values of 0.52 and 0.54 for postweaning growth rate, 0.70 and 0.62 for final weight after performance test or in feedlot, respectively. The estimated heritability values for feed intake range between 0.35 and 0.76 according to Preston and Willis (1970). Косн et al. (1973) found a genetic correlation estimate of +0.64 between daily gain for a postweaning period of 160 days and daily feed intake (adjusted for mid-weight).

- In these conditions, a very close genetic correlation generally appears between growth rate and the economic character (feed efficiency) measured by the ratio of gain to feed (or inversely) consumed in the same period, as shown by numerous experimental data $\left(r_{g}=-0.32\right.$ to -0.79 for Preston and Willis, 1970 ; - $0.87,-0.96$ for Neimann-Sorensen and ANDERSE. cited by KraUSSICH, 1974 in Danish cattle) and demonstrated theoretically as well by SutherLand (1965).

- Therefore, as clearly proved in long term selection experiments in laboratory animals (SUTHERLAND, 1974) and illustrated in table I for beef cattle, selection on growth rate is very efficient to improve feed efficiency : at least about $80 \mathrm{p}$. 100 of the improvement expected by direct selection.

- Selection for feed intake is less effective to improve growth (64 p. 100 of direct response) but could in some adequate cases (product of ratios of heritabilities and variation coefficients of gain to feed exceeding about 1.8 : Suthr.rLAND, 1965) also be efficient for increasing the feed conversion (table I; SUtherland et al., I974).

- But direct selection for feed efficiency itself is the most effective for improving this trait since increase is obtained more by increasing the growth than the feed intake as compared to what happens when selecting on growth. 
TABLE I

Relative direct and indirect expected responses to individual selection on postweaning gain (G), daily feed consumption (F) and two measures of conversion efficiency adjusted gain for feed $\left(\mathrm{G}_{\mathrm{A}}\right)$ and ratio $(\mathrm{G} / \mathrm{F})$ according to genetic and phenotypic parameters of KocH et al. (1963).

Réponses relatives directes et indirectes à une sélection individuelle sur la vitesse de croissance après sevrage (G), la consommation alimentaire journalière (F) et deux mesures de l'efficacité alimentaire : la vitesse de croissance ajustée pour la consommation (G/A) et le rapport (G/F) d'après les paramètres génétiques et phénotypiques de Kосн et al. (1963).

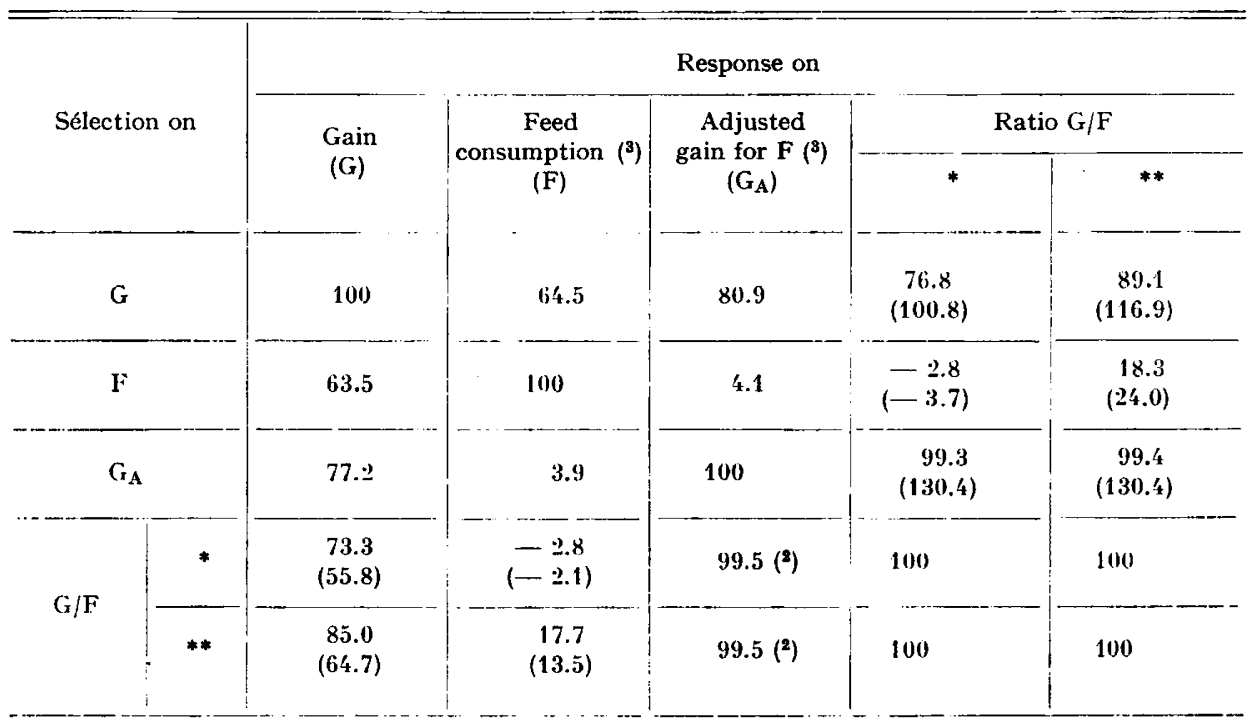

- In row $(i)$ and column $(j)$ is the ratio of correlated response on $(j)$ by selecting on $(i)$ to direct response on $(j)$.

- Parameters used according to Косн et al. (1963).

$$
\begin{aligned}
h^{2}= & 0.65 ; 0.64 ; 0.62 \text { and } 0.62 \text { or } 0.36 \text { for } \mathrm{G}, \mathrm{F}, \mathrm{GA}, \mathrm{G} / \mathrm{F}\left(0.62 \text { is the theoretical } h^{2}\right. \text { of the } \\
& \text { ratio calculated from SutherLAND }(1965) ; 0.36 \text { is the direct estimated value and } \\
& \text { corresponding responses are figured within brackets }) \\
r_{g}= & 0.64 ; 0.79 ; 0.75^{*} \text { or } 0.87^{* *} \text { between } \mathrm{F} ; \mathrm{G}, \mathrm{GA}, \mathrm{G} / \mathrm{F} \text { respectively } \\
= & 0.04 ;-0.028^{*} \text { or } 0.18^{* *} \text { between } \mathrm{G} ; \mathrm{GA}, \mathrm{G} / \mathrm{F} \text { respectively. }
\end{aligned}
$$

Correlations between G/F; F, G are calculated following SutherLand's formula with 2 sets of coefficients of variation (C) for $G$ and $F$ :

$$
\begin{array}{rl}
* \mathrm{CG}=0.15 & \mathrm{CF}=0.10 ; \\
* * \mathrm{CG}=0.20 & \mathrm{CF}=0.10 .
\end{array}
$$

(1) Calculated response from $a(\mathrm{G} / \mathrm{F}) / \mathrm{G} / \mathrm{F}=d \mathrm{G} / \mathrm{G}-d \mathrm{~F} / \mathrm{F}$.

$\left({ }^{2}\right)$ Rough estimation derived from SurHertand's formula.

$\left.{ }^{3}\right)$ Adjusted for mid weight on the 160 day feeding period.

As a matter of fact, efficiency of selection on growth for feed efficiency appears, to a great extent, to be due to an indirect selection for appetite. КосH et al. (1973) evaluated to $40 \mathrm{p} .100$ the amount of genetic differences in feed consumption which explains genetic increase of gain. For other authors : TAYLor and FIrzhugh, (1968) in cattle; TImoN and EIsen (I970) and SUTHERLAND (I974) in mice, increased feed efficiency by selection on growth should essentially 
result in increase of appetite, but in no change of net intrinsic feed efficiency of tissue growth in opposition to the figures of Косн and table $\mathbf{r}$.

- Another important question is the influence on body composition of selection on growth or feed efficiency. Since selection for growth will alter the shape of the growth curve increasing particulary the mature weight and modifing the degree of maturity, change in the body composition can be expected. Timon and EISEN (1970), Sutherland et al. 1974) report that fastly growing lines of mice show higher fatness percentage at constant age 7 and $15 \mathrm{p}$. Ioo fatter than the controls, for males and females at 49 days of age for generation 42 in SutherLand's experiment) and even, but to a less extent, at constant weight. The same tendency could be expected in beef cattle from the results of genetic analysis of maturing patterns made by FitzhUGH and TAYLOR (1971); SMIth et al. (1975). Since there are a relatively large amount of genetic variablity of the degree of maturity until $\mathrm{I} 8$ months and positive genetic correlations between, on the one hand the degree of maturity and, on the other the weight at the same age and growth rate during this period, selection for increased growth rate or final weight at coustant age will increase average degree of maturity at this age and therefore fatness.

On a within breed basis, Preston and Willis (1970) give experimental evidence of this fact that, on a constant age basis, faster growing animals exhibit fatter carcasses. But, on a fixed end-weight basis, there is either no change or the animals will be leaner. Selection on feed efficiency would lead to the same tendency for leaner carcasses as reported by these authors. Thus, recording of feed or/and carcass assessment can be justified in order to limit the unfavorable effect of increased appetite on fatness at a given age by selecting on growth only.

However, as the final objective must be measured on an economic basis (value of carcass less feed and time variable costs) usefulness of the different criteria (growth, feed-intake, body composition) appears to be not so easy to elucidate and will also depend on reference or/and production systems (constant weight, constant age or constant degree of finish). Thus, Dickersox et al. (1974) studying selection indices to predict the economic efficiency during postweaning period, found that more emphasis should be laid on reduction of back-fat and feed intake on a weight constant basis than on an age constant basis ; these two criteria add very little as compared to accuracy obtainable from weaning weight and postweaning gain $(\mathrm{R}=0.56$ vs 0.59 respectively).

These theoretical considerations are very important for defining test procedures as argued by Kraïssich et al. (1974) in a cattle commission of the E.A.A.P. It is sure that in the light of present knowledge on these topics, especially genotype-environment interactions which would be interesting to consider in connection with so different types of production and management systems as those existing in France, it is often difficult to take decisions without compromises.

\section{SELECTION FOR GROW'TH WI'TH LIMITATION}

\section{OF BIRTH WEIGHT}

As well established by MÉsissier (1975) the choice of the optimum combination of parental breeds allowing production of the heaviest veal or yearling calves without exceeding the critical threshold of calving difficulties can certainly be planned more objectively. This procedure offers the possibility of using a large range of sire lines, on account of the diversity in size and calving ability of indigeneous dam populations, the effect of age of cows and the replacement rate combined with maximum possible rate of crossing (Cunningham and McClintock, I974; ElseN and Mocovot, 1976 a).

In crossbreeding schemes, which take into account the age of the cows by use of different kinds of sires for young and mature cows, selection policy, particularly for growth, might be very different for these two situations. 


\section{A. - Genetic increase in birth weight due to present section for growth}

Since the main economic traits such as weaning and yearling weight are strongly correlated genetically with birth weight, selection for growth practised at present will indirectly increase birth weight and also the direct paternal component of calving difficulties (table 2 ; BELIC and Menissier, I968; Foulley et al., 1975).

\section{TABLE 2}

Some results of heritability estimates for birth weight, weaning weight and final weight and of their estimated genetic correlation with birth weigth.

Estimées de l'héritabilité des poids à la naissance, au sevrage et final et de leur corrélation génétique avec le poids à la naissance.

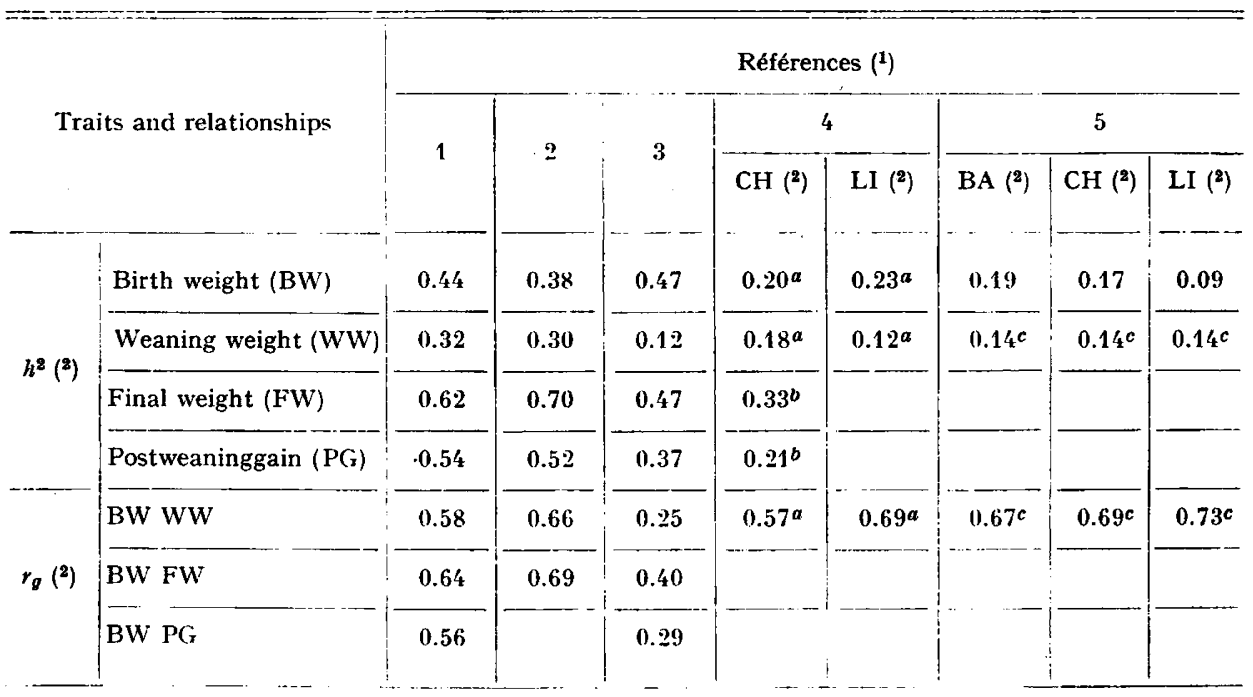

(1) References :

1. Petty, Cartwright (1966) : Weighted estimates and parental half-sibs analysis.

2. Preston, Willis (1970) : Review.

3. Косн et al. (1974) : Estimated regression on midparent averaged over 3 selected lines for $w w$, $y w$, index of $y w$ and muscling score for 10 years of selection.

4. a) Molinufvo, Vissac (1972); Genetic parameters estimated from dam-progeny regression coefficients on field recorded data including 12361 Charolais and 2928 Limousin pairs ;

b) MÉNISSIER et al. (1975) : Heritability estimates of 270 day-weight and gain between 9 and 18 months on 1067 Charolais paternal half sisters (55 sires) recorded in station from weaning till 30 months of age.

5. Foulley et al. (1975) : Paternal half sib analysis from progeny-test data on 4696, 12824 and 16765 pure and crossbred veal calves sired by 94 Blonde d'Aquitaine 256 Charolais and 374 Limousin young AI bulls.

c) 75 day weight instead of 6-7 month-weight in other references.

(2) Abbreviations :

$h^{2}, r_{g}$ : Coefficient of heritability and of genetic correlation respectively

BA, CH, LI : Blonde d'Aquitaine, Charolais and Limousin breeds respectively. 
This theoretically expected increase of birth weight due to selection is generally well confirmed by field and experimental data. Under French conditions of field progeny-testing of AI bulls for veal production on 75-day-weight and muscling score, the genetic superiority in birth weight of selected bulls over contemporary tested bulls is estimated to be $+0.4 \mathrm{~kg}$ for the Limousin breed (Foulley and Gaillard, r975 unpublished). Poivey (1973) found similar values of +0.54 and +0.61 for Charolais and Blonde d'Aquitaine bulls, respectively. As a matter of fact, genetic change will increase with improved efficiency of the different selection stages involved in the selection scheme of AI terminal beef bulls (GaILlaRD et al., 1974).

Thus, for instance, in an individual selection experiment carried out on 3 Hereford lines for weaning weight, yearling weight and index of yearling weight and muscling score, KoCH et al. (1974) observed over a ro year-period, substantial genetic responses on birth weight in al three lines ; mean change was estimated to be $0.22,0.28$ and 0.28 (expressed in standard deviation units : about $\mathrm{I} \mathrm{kg}$ ) per generation in weaning weight, yearling weight and index lines, respectively. From a theoretical point of view, with individual and progeny selection rates of $1 / 4$ and $1 / 3$, respectively, a genetic change of about +1.5 to +2 p. roo per generation can be expected on birth weight by selecting bulls on yearling weight.

So, it seems very important to control genetic change in birth weight. In France, the set up of a national sample of reference bulls in each beef breed since I97I will be very useful for this purpose (Colleau et al., I974; Foulley and Gaillard, 1975). Thereby, it might be relevant to consider for the case of a terminal sire line, selection for growth with some limitation with respect to birth weight since direct selection for rate of birth difficulties would not be as efficient unless a very high number of progeny are recorded $\left(25^{\circ}\right.$ to 300 progeny according to Mahon and CunNingham, I975).

\section{B. - Efficiency of restricted indices}

Using the theory of restricted indices and calculation procedures developed by MALLARD (1972), Foulley and Rouvier (I97I) primarily studied genetic consequences of imposing the restriction of no genetic improvement in birth weight for AI terminal beef sires. This restriction leads to a 58 and $74 \mathrm{p}$. Ioo reduction of expected genetic improvement in 75 dayweight in Charolais and Limousin calves and to 22 and $46 \mathrm{p}$. 1oo lowering of the economic value. The same restriction has been applied by MoLinuevo (1971) for individual and progeny selection of Charolais and Limousin bulls used in purebreeding; his results imply similar conclusions as far as relative genetic cost of restriction in the two breeds is concerned (Foulley and Molinuevo, 1971). In the same situation of purebreeding, Fitzhugh (1975) compared convientional growth criteria (12 month-weight, absolute growth rate) with relative growth rate and restricted selection indices with no change either in mature weight or in mature and birth weight (table 3).

Relative growth rate seems to be a very powerful mean (much more than absolute growth rate) for reducing especially the genetic increase in birth weight. But it implies higher reduction in yearling weight than restricted index selection for mature weight or both mature and birth weight (-II3 vs -27 p. I00; table 3). Thus, for the particular purpose discussed here, the use of restricted selection indices seems to be more advantageous.

As a matter of fact, such absolute restriction on birth weight is an extreme goal. Perhaps, some intermediate restrictions might be more realistic since the relation between the restriction on birth weight and the corresponding decrease of weaning or yearling weight is not linear (Foulley and MENIsSier, I975 ; fig. I) For instance, in the case of a progeny selection for yearling weight with 20 calves per sire, genetic increase of birth weight can be theoretically reduced by $50 \mathrm{p}$. 100 when selecting on "yearling weight minus 2.4 times birth weight " with a corresponding decrease of improvement for yearling weight of only $7.5 \mathrm{p}$. 100 vs $25 \mathrm{p}$. Ioo with the absolute restriction of no change in birth weight (Foulley, 1975, unpublished). These results are 


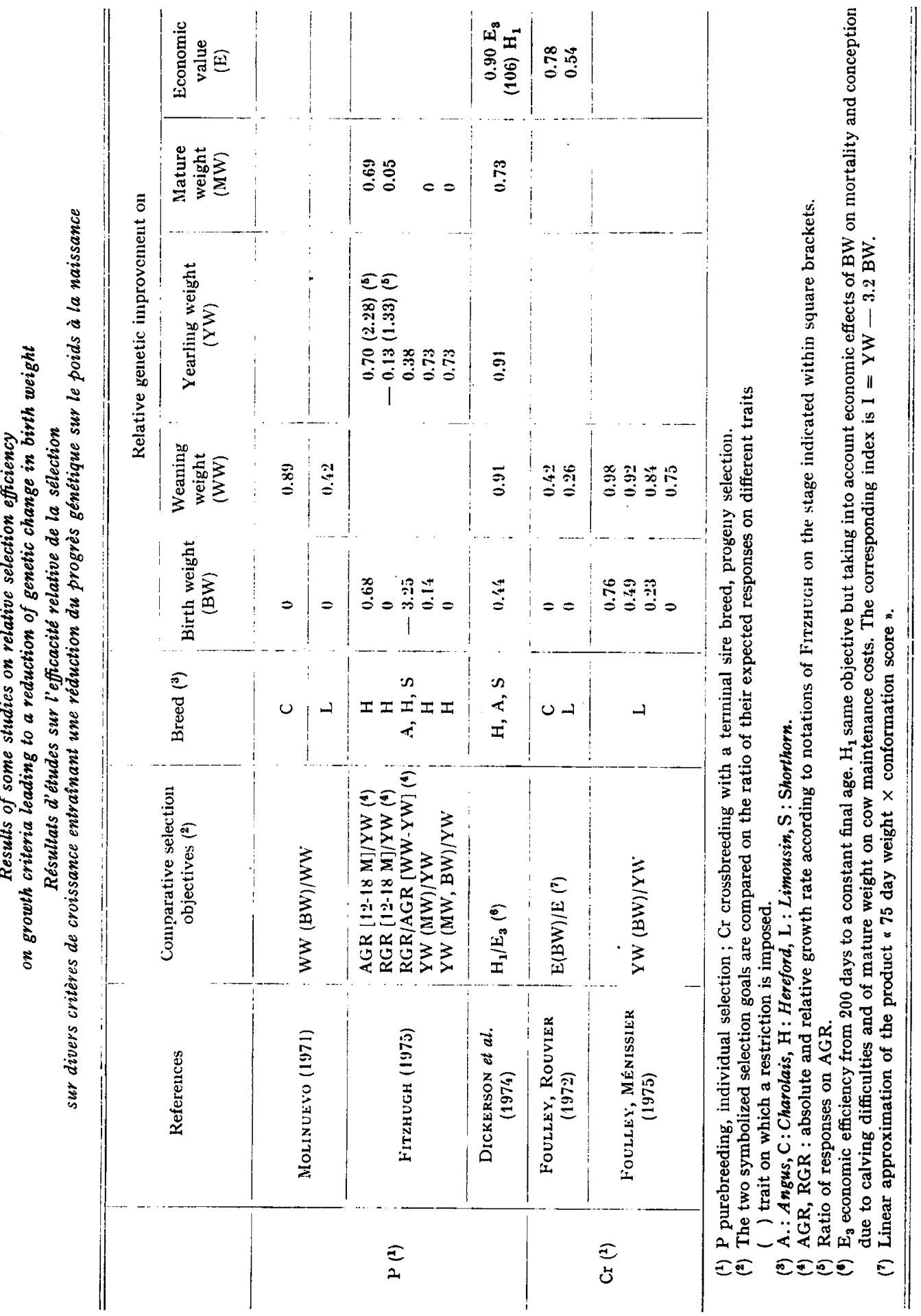


in good agreement with those of Dickerson et al. (1974) established by somewheat different reasoning and genetic parameters. Selecting on "yearling weight minus 3.2 times birth weight" to improve the economic efficiency of beef production from weaning to slaughter on a constant age basis including expected changes in cow-herd costs from associated increases in mature and birth weight, they found reductions of expected genetic improvement in birth and yearling weight of 56 and $9 \mathrm{p}$. Ioo respectively. For this purpose it can also be suggested to apply the independent culling levels, although they are theoretically less efficient (loss of 18 to $3^{8}$ p.roo for total selection rates on 75 day-veight varying between 5 and 50 p. roo respectively, according to Foulley and Ménissier, 1975).

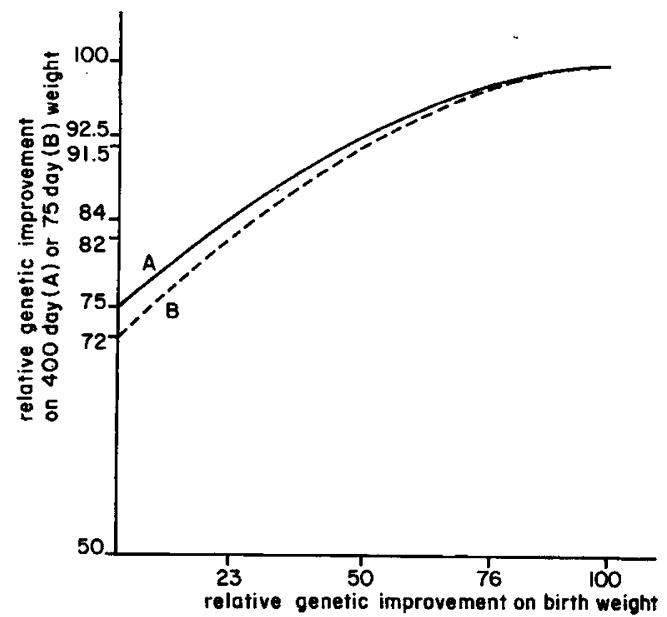

Fig. I. - Some results about selection indices with restriction on birth weight applied to bulls of terminal crossing

Résultats concernant l'application aux taureaux de croisement terminal d'indices de sélection avec contrainte sur le poids à la naissance

Note :

- The curves refer to two situations of selection :

(A) selection for 400 day-weight after progeny-test in station with 20 progeny per bull;

(B) selection for 75 day-weight after field progeny-test with 60 progeny per bull (Foulley and MÉNISSIER, I975).

- The absolute expected responses (value roo) are for one generation of selection of bulls with a standardized selection differential of one :

0.67 and $\mathrm{r} .32 \mathrm{~kg}$ for birth weight in (A) and (B) respectively ;

15.84 and $5.14 \mathrm{~kg}$ for 400 day-weight (A) and 75 day-weight (B) respectively.

- The coefficients $(\mathrm{K})$ to apply to birth weight $(\mathrm{BW})$, relatively to final weight (FW ; 400 or 75 dayweight) in selection indices ( $\mathrm{I}=\mathrm{FW}+\mathrm{K} . \mathrm{BW})$ are in these two situations.

(A) : $-5.40 ;-3.95 ;-2.43 ;-0.83$ and 0.88 for relative genetic improvement on birth weight of $0 ; 23 ; 50 ; 76$ and 100 p. roo respectively;

(B) : $-\mathrm{r} .75 ;-1.37 ;-0.92 ;--0.36$ and 0.35 respectively in the same conditions.

- Parameters used in (A) :

$h^{2}=0.10$ and 0.40 for heritability of birth and 400 day-weight respectively ;

$r_{g}=0.45$ and $r_{p}=0.09$ for genetic and phenotypic coefficient of correlation;

$\sigma_{p}=5$ and $30 \mathrm{~kg}$ for phenotypic standard deviation of birth and 400 day-weight respectively.

\section{C. - Discussion}

Even if it seems theoretically feasible to improve weaning or/and yearling weight by selection with little genetic change in birth weight, it may however be asked whether such kind of selection is really efficient. 
In spite of a large variability in observed responses between replicates, the selection methods based on restricted indices or independent culling levels prove generally to be effective as attested especially by results of SHERIDAN and BARKer (1974) in Drosophila, OKADA and HARDIN (1967) in Tribolium castaneum and McCARThy (I97I) in mice. However, in such antagonistic selection "genetic correlation may be more powerful in impeding component responses than predicted from presently available theory " as concluded by RUTLEDGE et al. (I973) from data of a selection experiment in mice on tail length and body weight. Which is the effect of this selection on the change of genetic correlation ? It will be theoretically increased when selecting on a restricted index according to simulation studies of ScHLore (r970).

Finally, these preliminary studies suggest some methods of selection in order to improve calving ability. Other predictor traits such as calf morphology and gestation length can be considered.

The efficiency of these selection criteria have also to be discussed, especially concerning the consequences of direct selection for reduced gestation lengt on calf mortality and calving difficulties.

\section{ECONOMIC OPTIMIZATION OF THE SELECTION SCHEME}

\section{FOR TERMINAI, SIRE, LINES}

The development of AI in cattle and the wide diffusion of genetic progress owing to frozen semen techniques as well as the national organization of breeding by the livestock act of 1966 have allowed the setting up of large and powerful selection units. This is the case now in France for selection of terminal beef sire lines. In spite of the obvious advantages of these large structures, the decisions which have to be taken in order to develop profitability of AI industry and breeders become rather complicated. Under these conditions and taking into account the importance of the national outlay for this purpose, it appears necessary to develop synthetic studies for comparing the different selection alternatives. These studies must take into account not only animal genetic improvement, but also costs implied by selection operations, returns expected by breeders through better performance of calves sired by selected bulls and different time flows of costs and returns according to selection progranmes.

Since the early work of Poutous and VISSAC (I962), many studies have been made in this area essentially for dairy or dual purpose populations. Primarily these studies have clearly demonstrated :

\section{A. - The interest of use and selection \\ of terminal sire beef breed especially in dual purpose populations}

Anderson and Lindhe (1973), Cunningham (1974) have shown the favourable effect of increasing the rate of terminal crossing on dual purpose or dairy breeds for increasing the total beef production provided that the beef breeds used show some higher (but relatively modest) beef progeny performance than straight-dairy progeny.

Furthermore, an increased beef crossing improves the return for investment of dairy selection since the dairy merit is transmitted to the population by fewer inseminations (Cunningham and McClintock, I970).

In these conditions where terminal crossing is practised on a dual purpose population, CunNINGHAM (1974) suggested that a selection within the terminal crossing breed would be economically effective : 1 p. roo of improvement in a beef crossing breed used in $40 \mathrm{p}$. roo of a cow population of $\mathrm{I}$ million would give an annual benefit of 1.17 million UA $\left({ }^{1}\right)$ which would justify the setting-up of the selection programme. HiLl (I97I) concluded in the same way for a population of the same size with 25 p. I oo of terminal crossing. Furthermore, he showed that selecting

(1) Enit of Account. 
in the beef breed for beef characteristics leads to a better profitability than selecting within the dual purpose breed : on a 20 year-evaluation period the rate of return was estimated to 27 and I6 p. Ioo, respectively. But practically no attempt was made to study the optimum design of the selection programme.

\section{B. - Optimization of selection procedures within terminal beef breeds}

Considering now the French suckling cow population of dual purpose and hardy breeds crossed with beef breeds mainly for veal production. Mocouot and Foulley (1973) compared the following three selection methods :

- selection on a station performance test (1 2 month-weight) ;

...- selection on a field progeny test ( 3 month-weight) with 50 progeny per sire ;

-.. selection in two stages : at first, on individual performance and then on the breeding value for 3 month-weight estimated from the performance at the two stages.

Two stage selection appears to be the best way for selecting bull sires since it does not only provide the best profitability for the most probable values of genetic parameters, but it is also less sensitive to their variation.

Two stage selection is always more efficient than progeny selection alone. It is also better than performance test selection except in the case of a low heritability coefficient for 3 monthweight $\left(h^{2}=0.10\right)$ and a high correlation $(\mathrm{R}=0.4)$ between individual and progeny performance. When this correlation is low $(R=0.2)$, the selection after performance test becomes rather inefficient.

Although generally this does not seem to occur, especially with the same recorded traits, we can imagine that for very specialized terminal strains (such as double muscled) needing a very protected environment, individual performance under current conditions might be negatively related with the economic value of their crossbred progeny (VIssac, personal communication).

On the other hand, as reported by Mocouot (1972), comparison of performance and progeny test will also depend on the relative importance of veal and yearling calves. When the relative number of these latter calves exceeded $\mathrm{I} / 4$, he concluded that, on a constant cost comparison basis, performance test on yearling weight becomes more interesting than progeny test on 3 month-weight.

The commercial use of no selected bulls except they are sons of the best proven bulls justifies by itself the investment made. But, as reported also by HILl (1971), a choice of these bulls after performance test enhances the profitability of selection.

Therefore, performance and progeny test will have quite different goals. Even if the latter remains of high interest for detecting elite bulls, it will not necessarily be applied to bulls before a commercial use, provided they are sons of proven sires. Besides, the choice of bulls for this purpose and also at all stages, will be improved if cumulative information procedures such as the one proposed by Colleau and Poutous (1973) are applied. Finally, different ways using not only AI can be imagined for disseminating genetic improvement realized through the best proven sires.

\section{CONCLUSION}

An attempt has been made to gather all elements available in order to define optimum selection schemes of bulls for terminal crossing.

As far as the application is concerned, it clearly appears that goals and schemes have to take into account :

- the differences in age and genetic types of females to be crossed;

- the reproduction conditions : AI $v s$ natural service in various environments. 
Should we select several lines adapted to each goal ?

Or should we take advantage of the efficient integrated schemes devoted to increasing as much as possible muscle development in order to produce for other situations (mating of heifers, natural service), the most fitted bulls by crossing those from integrated schemes with various females adapted to each particular case ?

Truth lies probably between these two possibilities. Selecting several terminal sire lines cannot be avoided since this aim will be pursued in several populations and countries in order to realize particular production objectives or to promote breeding stocks.

Moreover, the prospect of developing techniques for ova transplantation and possible control of sex ratio in the future will unavoidably lead to a better efficiency of selection through the dam path (LAND and Hill, r975; Elsen and Moceuot, $1976 b$; CunNinghaM, I975). Integrated selection units for terminal sire lines are favourable structures for this purpose.

Reçu pour publication en février 1976.

\section{ACKNOWLEDGEMENTS}

The author is indebted to Messrs. B. Vissac, F. Ménissier and B. Bonaiti for their helpful suggestions and comments during the preparation of this paper and to Mrs. Kirsten RERAT for her valuable assistance in translation.

\section{RÉSUMÉ}

\section{CRITÈ RES ET OPTIMISATION DE LA SÉLECTION DES RACES A VIANDE POUR LE CROISEMENT TERMINAL}

L'efficacité de la sélection des races bovines à viande pour le croisement terminal a été analysée sous l'angle du choix des critères de sélection relatifs à la croissance et des méthodes de sélection des mâles, en référence notamment à la situation et aux recherches françaises.

L'intérêt dans la sélection des souches à viande spécialisées, du contrôle de la consommation alimentaire individuelle et des performances de carcasse par rapport à celui de la seule croissance est discuté brièvement; il convient de prendre en compte, à cet égard, non seulement la réponse indirecte favorable sur l'indice de consommation due a la sélection basée sur la seule croissance, mais aussi l'accroissement de consommation et les modifications de composition corporelle qui en découlent selon le système de référence considérée (poids, durée, âge).

Compte tenu de l'augmentation du poids à la naissance dû à l'intensification de la sélection pratiquée dans les races à viande sur la croissance musculaire et de la forte corrélation génétique qui existe entre ce poids et la composante paternelle des difficultés de vêlage, il semble opportun d'envisager l'utilisation d'indice de sélection avec contrainte sur le poids à la naissance, du moins pour les souches de croisement terminal utilisées sur génisses.

En fin, dans la situation française du croisement terminal pratiqué sur des femelles allaitantes de races mixtes ou rustiques, en vue d'une production de veaux de boucherie, l'accent a été mis sur l'intérêt génétique et économique d'une sélection en deux étapes pour choisir les pères à taureaux (choix individuel en station sur le poids à un an ; choix sur descendance en ferme sur le poids à 3 mois). Si le contrôle sur descendance demeure ainsi indispensable pour effectuer ce choix, il n'est pas nécessaire de l'appliquer aux taureaux d'IA avant leur mise en service commercial ; un tri après contrôle individuel peut suffire à ce propos pourvu qu'il soit réalisé sur des fils de taureaux d'élite.

\section{REFERENCES}

Andekson J., Lindhé B., r973. Optimum use of beef semen in a dual purpose or dairy breed. Acta A gric. Scand., 23, 102-108.

Belic M., Ménissier F., I968. Étude de quelques facteurs influençant les difficultés de vêlage en croisement industriel. Ann. Zootceh., 17, 107-142. 
Cartwright T. C., Fitzhugh H. A. Jr., 1974. Efficient breeding system for commercial beef production. 1st. world congr. genet. appl. Livest. prod., Madrid, I, 643-654.

Colleau J. J., Poutous M., 1973. Méthode de calcul des index de production laitière des femelles en France. Ann. Génét. Sél. anim., 5, 73-82.

Colleav J. J., Foulley J. L., Gaillard J., 1974. Le lot témoin dans le contrôle des taureaux de race à viande française sur descendance croisée : intérêt pour la mesure du progrès génétique. Ann. Génét. Sél. anim., 6, 24 r-252.

Cundify L. V., 1974. Crossbreeding research at the U.S. Meat Animal Research Center. Proc. Working Symp. Breed Evaluation and Crossing Experiments, Zeist, Netherlands.

Cunningham E. P., r974. The economic consequences of beef crossing in dual purpose or dairy cattle populations. Livest. Prod. Sci., 1, r33-r 39.

Cunningham E. P., McClintock A. E., 1974. Selection in dual purpose cattle populations : Effect of beef crossing and cow replacement. Ann. Génét. Sél. anim., 6, 227-239.

Cunningham E. P., 1975. The effect of changing the sex ratio on the efficiency of cattle breeding operations. Livest. Prod. Sci., 2, 29-38.

Dickerson G. E., Nicklaus Kunzi, Cundiff L. V., Koch R. M., Arthaud V. H., Gregory K. E., 1974. Selection criteria for efficient beef production. J. Anim. Sci., 36, 659-673.

Elsen J. M., MocQuot J. C., I976a. Optimisation du renouvellement des femelles dans les troupeaux laitiers soumis au croisement terminal. Ann. Génét. Sél. anim. (submitted).

Elsen J. M., Mocquot J. C., 1976 b. Intérêt de la transplantation d'œufs pour accroître l'efficacité de la sélection des bovins à viande. Ann. Gênét. Sél. anim. (submitted).

Fitzhugh H. A. Jr., Taylor Stc. S., I97I. Genetic analysis of degree of maturity. J. Anim. Sci., 33, 717-725.

Fitzhugh H. A., Jr., 1975. Alternatives measures of growth in relation to feed efficiency and shape of growth curve. Beef Impr. Fed. Symp. "A new look at growth ", Des Moines, Iowa, May 20, 1975, p. 9.

Foulley J. L., Molinuevo H. A., 1971. Possibilités de modification par sélection de la forme de la courbe de croissance avant sevrage des veaux de races à viande française. Xe Congr. Int. Zootech., Paris-Versailles, I7-23 juillet, theme VII, p. 5 .

Foulley J. L., Rouvier R., I97I. Méthodes d'établissement des index de sélection des taureaux de races à viande sur la valeur économique de leurs descendants. Ann. Génét. Sél. anim., 3, 497-507.

Foulley J. L., Gaillard J., r975. Utilisation du lot témoin dans les schémas de sélection des taureaux de races à viande pour le croisement industriel : principes et résultats. Bull. tech. Dép. anim. (Inst. nat. Rech. agron., Fr.), 18, 60-68.

Foulley J. L., Ménissier F., Gaillard J., Nebrada A. M., I975. Variabilité génétique des effets directs paternels sur la croissance, la conformation bouchère et les conditions de naissance dans les races Blonde d'Aquitaine, Charolaise et Limousine utilisées en croisement pour la production de veaux de boucherie (in preparation).

Foulley J. L., MÉnissier F., 1975. Note sur certaines possibilités de sélection des taureaux de croisement terminal avec limitation du poids à la naissance : cas du contrôle de descendance en ferme sur la production de veaux de boucherie en race Charolaise (in preparation).

Gaillard J., Foulley J. L., Ménissier F., r974. Observations sur l'efficacité du choix sur ascendance paternelle et performances individuelles de taureaux de races à viande destinés au croisement terminal. Ier Congr. Mond. Génét. appl. Elev., Madrid, 3, 877-887.

GREgory K. E., 1965. Symposium on performance testing in beef cattle. Evaluation postweaning performance in beef cattle. J. Anim. Sci., 24, 248-254.

Hil. W. G., 197I. Theoretical aspects of crossbreeding. Ann. Genét. Sél. anim., 3, 23-34.

Hill W. G., 1971. Investment appraisal for national breeding programmes. Anim. Prod., 13, 37-50.

Koch R. M., Swiger L. A., Chambers Doyle, Gregory K. E., rg63. Ffficiency of feed use in beef cattle. J. Anim. Sci., 22, 486-494.

Koch R. M., Gregory K. E., Cundiff L. V., 1974. Selection in beef rattle. II. Selection response. J. Anim. Sci., 39, 459-470.

KRA ÜSSI.ICH H., I974. General recommandations on procedures for performance and progeny testing for beef characteristics. Livest. Prod. Sci., 1, 33*45.

LAND R. B., Hill W. G., 1975. The possible use of superovulation and embryo transfer in cattle to increase response to selection. Anim. Prod., 21, I-12.

Mahon G. A. T., Cunningham E. P., 1975. Statistical Efficiency in Bull Progeny Testing for Calving Difficulty. 26th an. Meet. eur. Ass, anim. Prod. Warsaw, Poland, 23rd-27th June 1975.

Mallard J., 1972. La théorie et le calcul des index de sélection avec restriction : synthèse critique. Biometrics, 28, 713-735.

McCARTHY J. C., I97I. Effects of different methods of selection for weight on the growth curve in mice. Xth Intern. Congr. anim. Prod., Paris-Versailles, 17-th-23rd, July.

MÉnissif:R F., 1975. Calving ability in french beef breeds : Analysis of components and breeding improvement. in Bull. tech. Dep. Génét. anim. (Inst. nat. Rech. agron., Fr.), 21, 60-102.

Ménissier F., Vissac B., Frebling J., 1975. Optimum breeding plans for beef cattle. In Bull. tech. Dép. Génét. anim., (Inst. nat. Rech. agron, Fr.), 21, 8-56. 
Ménissier F., Foulley J. L., Gogué J., 1975. Estimation des paramètres génétiques et phénotypiques en race Charolaise, pour les génisses vêlant à 2 ar:s en station de contrôle des qualités d'élevage, (in preparation).

Moav R., 1966. Specialised sire and dam lines. I. Economic evaluation of crossbreds. Anim. Prod. 8, 193-202.

Moav R., Hill W. G., r966. Specialised sire and dam lines. IV. Selection within lines. Anim. Prod., 8, 375-390.

MocQuot J. C., Foulley J. L., 1973. Recherche des conditions de rentabilité d'un schéma de sélection d'une souche de bovins destinés au croisement de première génération pour la production de veaux de boucherie. Ann. Génét. Sél. anim., 5, 189-209.

Mocovor J. C., I972. Recherches sur la rentabilité optimale du schéma de sélection des mâles de races à viande pour une production de veaux et (ou) de jeunes bovins. Journ. Fed. eur. Zootech., 7-ro octobre 1972, Vérone (Italie), p. 21.

Molinuevo H. A., I97I. Variabilité génétique de la croissance avant sevrage dans les races Charolaise et Limousine. Thèse Doct. $3^{\mathrm{e}}$ cycle, Fac. Sci., Paris, $34 \mathrm{p}$.

Molinuevo H. A., Vissac B., I972. Variabilité génétique de la croissance avant sevrage dans les races Charolaise et Limousine. Ann. Génét. Sél. anim., 4, 423-444.

OKADA L., HARDin R. T., 1967. An experimental examination of restricted selection index using Tribolium Castaneum. I. The results of two way selection. Genetics, 57, 227-236.

Petty R. R., Jr., Cartwright T. C., 1966. A summary of genetic and environmental statistics for growth and conformation traits of young beef cattle. Depart. tech. Rep., Texas AM University.

Poutous M., VISSAC B., I962. Recherche théorique des conditions de rentabilité maximum de l'épreuve de descendance des taureaux d'insémination artificielle. Ann. Zootech., 11, 233-256.

Porvey J. P., I973. Étude des liaisons entre les effets paternels sur la croissance postnatale chez les bovins à viande. Mémoire fin d'études, École nat. sup. agron. Montpellier, p. 66 (ronéoté).

Preston T. R., Willis M. B., 1970. Intensive Beef Production. Pergamon Press, Oxford, p. 567.

Rutledge J. J., Elsen E. J., Legates J. E., 1973. An experimental evaluation of genetic correlation. Genetics, 75, 709-726.

Scholte W., 1970. Simulation study on the restricted selection index. MS thesis, Cornell university, p. $6 \mathrm{I}$.

Sheridan A. K., Barker J. S. F., r974. Two-trait Selection and the Genetic Correlation. I. Prediction of Responses in Single-trait and in Two-trait selection. Aust. J. biol. Sci., 27, 75-88.

Smith C., 1964. The use of specialized sire and dam lines in selection for meat production. Anim. Prod., 6, 337-344.

Simith G. M., Fitzhugh H. A. Jr., Cundiff L. V., Cartwrightт C., Gregory K. E., I975. A genetic analysis of maturing patterns in Hereford, Angus and Shorthorn cattle. J. Anim. Sci. (submitted).

SutherLand T. M., r965. The correlation between feed efficiency and rate of gain : a ratio and its deminator. Biometrics, 21, 739-749.

Sutherland T. M., Biondini P. F., Ward G. M., 1974. Selection for growth rate, feed efficiency and body composition in mice. Genetics, 78, 525-540.

TAYLor St C. S., 1971. Selection criteria for improving food efficiency. Arg. Ass. anim. Prod., Symp. Corrientes, nov. 1971, r4 p. (ronéoté).

TAylor St C. S., Fitzhugh H. A., Jr., I968. Genetic relations among maturing rate, growth rate and feed efficiency. J. Anim. Sci., 27, 286 (abstr.).

Timon V. M., Eisen E. J., Leatherwood M. M., I97o. Comparisons of ad libitum feeding of mice selected and unselected for postweaning gain. II. Carcass composition and energetic efficiency. Genetics, 65, 145-I 55 . 